http://journal.uinsgd.ac.id/index.php/biodjati

\title{
THE GROWTH OPTIMIZATION OF PAK CHOY (Brassica rapa L. VAR. chinensis) IN HOUSEHOLD-SCALE AQUAPONICS SYSTEM
}

\begin{abstract}
Dody Priadi $^{1 *}$, Heru Wibowo ${ }^{2}$, Enung Sri Mulyaningsih ${ }^{3}$
Received : May 16, 2019

Accepted : August 02, 2019

DOI: $10.15575 /$ biodjati.v4i2.4630

${ }^{1,2,3}$ Research Center for Biotechnology - LIPI

Jl. Raya Bogor Km. 46 Cibinong 1691

West Java, Indonesia. Telp. +62-218754587, Fax. +62-21-8754588

e-mail:

*1dody004@gmail.com

²herunomor1@gmail.com

3enungmulyaningsih@gmail.com

*Corresponding author

Abstract. The growth of Pak Choy (Brassica rapa var. chinensis) using nutrients from catfish "Sangkuriang" (Clarias gariepinus) wastes was investigated in the household-scale aquaponics systems. The growth parameters were compared among the grow beds. The growth parameter of Pak Choy was fresh weight, leaf number, and leaf area. Meanwhile, catfish growth parameters were body weight and length, and feed conversion ratio (FCR). The experiments were arranged in a Completely Randomized Design (CRD) with 4 treatments and 3 replications. The data were analyzed using Analysis of Variance (ANOVA) followed by Duncan Multiple Range Test (DMRT) at a 95\% level of significance. The result of the study showed that there were not significantly different in the growth parameter of Pak Choy among the grow beds in the vertical system. However, those in grow beds "A" were significantly higher than the rest of the grow beds in the horizontal aquaponics system. In general, all the growth parameter of Pak Choy in the vertical system was higher than in the horizontal one, although, it was not statistically significantly different. Nevertheless, the horizontal aquaponics system gave better results in the body weight and FCR of catfish.
\end{abstract}

Keywords: aquaponics systems, Brassica rapa L. chinensis, Clarias gariepinus Pak Choy

\section{Citation}

Priadi, D., Wibowo, H. \& Mulyaningsih, E. S. (2019). The Growth Optimization of Pak Choy (Brassica rapa L. var. chinensis) in Household-Scale Aquaponics System. Jurnal Biodjati, 4(2), 175-183

\section{INTRODUCTION}

Vitamins and animal protein are necessary for improving family nutrition to improve the quality of human resources. This is in line with the Sustainable Development Goals (SDGs) Program (Goal 2. Zero Hunger). Unfortunately, the high price of a protein source is the problem for low-income communities. Self-sufficiency of vegetable and inexpensive animal protein for each family can be implemented using a household-scale aquaponics system. Aquaponics is the integration of aquaculture and hydroponics to produce vegetables and fish at the same time. Aquaponics is considered as the right choice for low-income communities due to nutrient supply for plant growth obtained from fish wastewater, unlike hydroponics that used expensive manufactured fertilizer. Hydroponics is a soilless plant culture system in a controlled environment which is becoming popular since it produced good quality vegetable in a limited space. However, the main disadvantage of hydro- 


\section{JURNAL BIDDJATI}

http://journal.uinsgd.ac.id/index.php/biodjati

ponic system is that the production depends on expensively manufactured fertilizers ( $\mathrm{Li}$ et al., 2018). Moreover, the use of only inorganic nutrients in the hydroponics resulted in residual effects on plants that impact on human health. It can be decreased by the addition of biofertilizer (Husnaeni et al., 2018). A hydroponic solution made from catfish wastewater and goat urine on Pak Choy was studied by Kuswoyo \& Zein (2018) to reduce the price of manufactured fertilizer and obtain a healthier product. Aquaponics resulted in a healthier product than hydroponics due to the empowering microorganisms to improve nutrition for plant growth. Aquaponic is, therefore, a user and environmentally friendly soilless fish and vegetable production system. (Salam et al., 2013; Surnar et al., 2015).

Pak Choy is one of favorite Chinese leafy vegetables in Indonesia and used in various dishes. Edible parts of $100 \mathrm{~g}$ of Pak Choy containing $1.7 \mathrm{~g}$ of protein, $0.2 \mathrm{~g}$ of fat, $3.1 \mathrm{~g}$ of carbohydrate, vitamins and minerals such as $\beta$-carotene $(2.3 \mathrm{mg})$, vitamin C (53 mg) and Calcium (102 mg) (Tay \& Toxopeus, 1994). An aquaponics of catfish "Sangkuriang" and Pak Choy has been previously conducted to identify the most effective vegetable plant to recover water quality (Damanik et al., 2018; Effendi et al., 2015). However, the study to compare the growth of Pak Choy among vertical and horizontal household-scale aquaponics system have not been previously carried out in Indonesia.

Catfish is a widely cultivated fish in Indonesia (Pratama et al., 2018) especially for the Indonesian traditional dish "pecel lele". Moreover, an international survey found that catfish is the most common for aquaponics system after tilapia and ornamental fish (Love et al., 2015). Bosma et al. (2018) suggested that the first aquaponics producers need to start with catfish before shifting to a high-val- ue fish species for niche markets. Aquaponics is one of the urban agriculture systems to obtained vegetable and protein self-sufficiency from a their-own family yard. This is expected to be a solution for the urban community, which has limited space for farming practices. Aquaponics is easier to operate than hydroponic systems due to the less monitoring of water quality (Rakocy et al., 2006). This study is aimed to identify the best growth and production of Pak Choy as well as catfish in two models of the household-scale aquaponics system due to the research on the household-scale aquaponics system in Indonesia is still limited.

\section{MATERIALS AND METHODS}

\section{Source of Plant and Fish Seed}

The study was conducted from July to September 2018 at the screenhouse of Plant Germplasm Garden, Research Centre for Biotechnology LIPI, Cibinong, West Java. The Pak Choy (Brassica rapa var. chinensis) seeds (Nauli F1, East-West Seeds $\left.{ }^{\mathrm{TM}}\right)(98 \%$ purity and $99 \%$ viability) used as a vegetable model. Whereas, the catfish "Sangkuriang" (Clarias gariepinus) (61.1 g weight and 23.3 $\mathrm{cm}$ length in average respectively) was used as an aquatic living organism in the aquaponics systems. The Pak Choy seed was obtained from a local farm shop in Bogor, while the catfish was obtained from a local fish breeder at Cibinong district, West Java. Each seed was germinated in the Rockwool medium $\left(1 \mathrm{~cm}^{3}\right.$ size) for 5 days and then placed in a perforated plastic cup (180 $\mathrm{ml}$ volume) in plastic trays $(37 \mathrm{x} 28 \mathrm{x} 4.5 \mathrm{~cm})$ prior transferred to the aquaponics systems.

\section{Experiment Design}

We used two types of household-scale aquaponics (vertical and horizontal) systems 


\section{JURNAL BIDDJATI}

http://journal.uinsgd.ac.id/index.php/biodjati

with nutrient film technique (NFT) method. The vertical system grow beds consists of four PVC (A to D) pipes arranged consecutively starting with the PVC pipe " $A$ " in the lowest, and pipe "D" in the $100 \mathrm{~cm}$ high above the fish tank, The horizontal system grow beds consists of four PVC gutters directly placed horizontally above the fish tank. Each PVC pipe or gutter has nine plant holes. Each plastic cup containing one Pak Choy seedling was then placed in each PVC pipe or gutter holes. According to Somerville et al. (2014), an aquaponics system with a fish tank size up to 1000 liters and growing space of about 3 $\mathrm{m}^{2}$ are appropriate for household-scale production (Figure 1). Water parameter $(\mathrm{pH}$, temperature, and TDS) was recorded daily for 5 weeks using handheld tester (Adwa AD11 and TDS-3 respectively). Both aquaponics systems were equipped with a gravel filter. The detailed technical specification of the aquaponics system was presented in Table 1 .
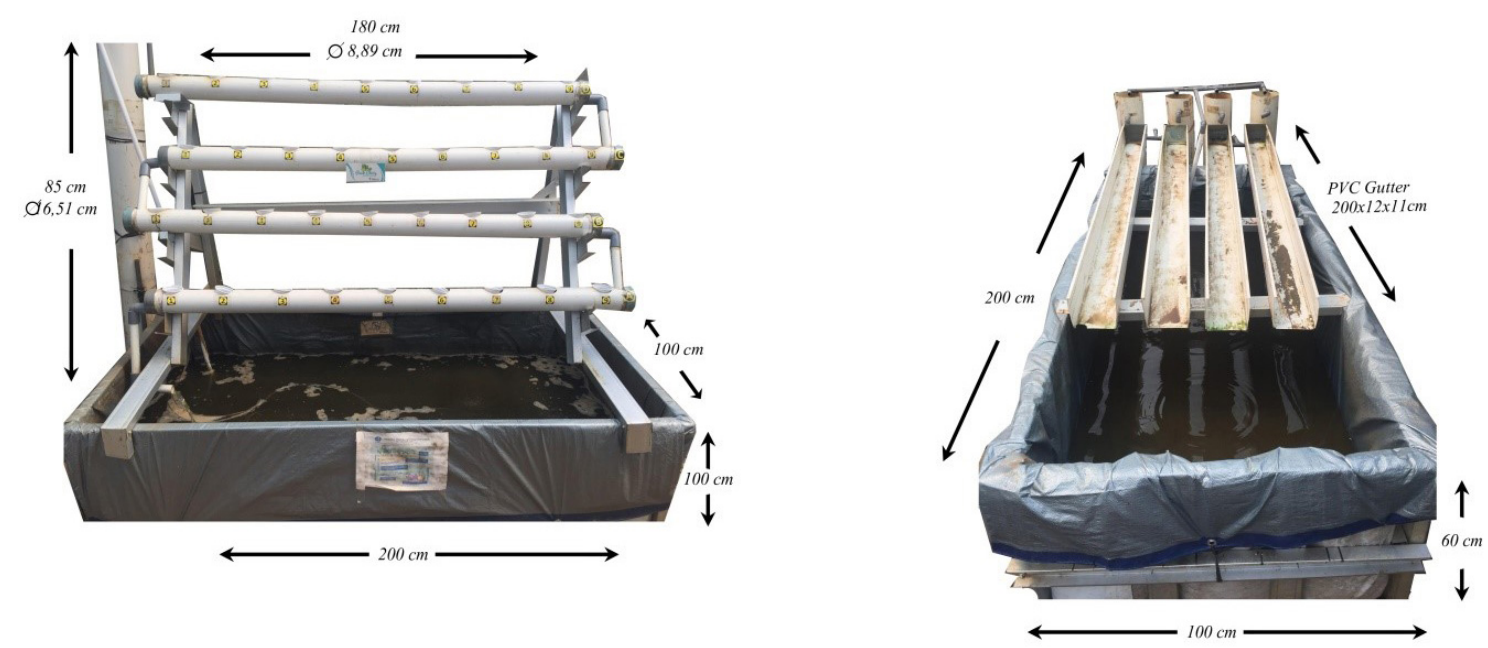

Figure 1. The household-scale of A. Vertical and B. Horizontal aquaponics system

Table 1. Technical specifications of household-scale aquaponics system

\begin{tabular}{|c|c|c|}
\hline \multirow{2}{*}{ Structure } & \multicolumn{2}{|c|}{ Type } \\
\hline & Vertical & Horizontal \\
\hline Frames material & \multicolumn{2}{|c|}{ Lightweight steel truss } \\
\hline Fish tanks material & \multicolumn{2}{|c|}{ Plastic sheeting } \\
\hline Grow beds & PVC pipe $180 \mathrm{~cm}(\mathrm{~L}) \times 8.89 \mathrm{~cm}(\varnothing)$ & $\begin{array}{c}\text { PVC gutter } 200 \mathrm{~cm}(\mathrm{~L}) \times 12 \mathrm{~cm}(\mathrm{~W}) \times \\
11 \mathrm{~cm}(\mathrm{H})\end{array}$ \\
\hline Fish tank dimension & $200 \mathrm{~cm}(\mathrm{~L}) \times 100 \mathrm{~cm}(\mathrm{~W}) \times 100 \mathrm{~cm}$ & $200 \mathrm{~cm}(\mathrm{~L}) \times 100 \mathrm{~cm}(\mathrm{~W}) \times 60 \mathrm{~cm}(\mathrm{H})$ \\
\hline Water volume & \multicolumn{2}{|c|}{$0,8 \mathrm{~m}^{3}$} \\
\hline Aerator capacity & \multicolumn{2}{|c|}{176 liters / min } \\
\hline Water flow rate & \multicolumn{2}{|c|}{6.3 liters / $\mathrm{min}$} \\
\hline Water filter materials & \multicolumn{2}{|c|}{ Gravel filter in PVC pipes, $85 \mathrm{~cm}(\mathrm{H}) \times 16.51 \mathrm{~cm}(\varnothing)$} \\
\hline Initial $\mathrm{pH}$ in average & \multicolumn{2}{|c|}{7,2} \\
\hline Initial TDS in average & \multicolumn{2}{|c|}{$101 \mathrm{ppm}$} \\
\hline Initial temperature in average & \multicolumn{2}{|c|}{$27^{\circ} \mathrm{C}$} \\
\hline
\end{tabular}




\section{JURNAL BIDDJATI}

http://journal.uinsgd.ac.id/index.php/biodjati

\section{Growth Parameters}

The growth parameters of Pak Choy were fresh weight, leaf number and leaf area. The fresh weight and leaf number were recorded weekly; however, the leaf area was recorded at the end of the observation (5th weeks after planting) from 3 samples of each PVC pipes (vertical system) or gutters (horizontal system). The catfish was maintained for two weeks in the fish tank prior to the Pak Choy seedlings were transferred into the aquaponics systems and fed $(2.5 \%$ of body weight) daily with floating type feed (Hi-ProVite 781) with the feed composition of 31$33 \%$ protein, $4-6 \%$ fat, $3-5 \%$, fiber and $9-10 \%$ water content. Fresh weight and leaf number of Pak Choy were recorded weekly using a digital balance and metal ruler, respectively. Meanwhile, the leaf area was calculated using a digital image analysis method (Bradshaw et al., 2007). Leaf area of Pak Choy, as well as FCR of catfish, was observed at the end of the observation period. The Feed Conversion Ratio (FCR) of catfish was calculated as feed consumed divided by weight gain during the culture period.

\section{Data Analysis}

The experiments were arranged in a Completely Randomized Design (CRD) with four treatments (grow beds position) and three replications (Pak Choy samples in each grow beds). Obtained data were analyzed using Analysis of Variance (ANOVA) followed by Duncan Multiple Range Test (DMRT) and processed using the SPSS 16.0 statistical software.

\section{RESULTS AND DISCUSSION}

\section{Pak Choy Growth Parameters}

Results showed that Pak Choy in the vertical aquaponics resulted in the average weight gain and leaf increase per week of $4.8 \mathrm{~g}$ and 2.7 leaves respectively, which was higher than in the horizontal aquaponics system (2.7 $\mathrm{g}$ and 2.0 leaves). The plant in the vertical system was exposed by the sunlight better than the horizontal system, due to its vertical structure, and therefore, it resulted in better plant growth. Demšar et al. (2004) stated that the plant growth and development was affected by daylight.

The survival rate of Pak Choy in both aquaponics system was $100 \%$ except for gutter $\mathrm{C}(88 \%)$ in the horizontal system due to the fungi infections. There was not significantly different in the leaf number, fresh weight, and total leaf area among the vertical aquaponics system grow beds. The highest growth parameters value of Pak Choy in the horizontal aquaponics system was in gutter "A". It was significantly different $(\mathrm{p}<0.05)$ among all gutters, with the exception of total leaf area in gutter C. In general, growth parameters value of Pak Choy in the vertical aquaponics system was higher than that in the horizontal (Table 2). However, this was higher than the Pak Choy fresh weight and leaf number in a hydroponic solution containing inorganic and organic nutrition (3:1) (Priadi et al., 2017). The highest average leaf number and fresh weight was 10.8 and $22.8 \mathrm{~g}$ respectively, and it was obtained from gutter " $\mathrm{A}$ ".

All growth parameter value of Pak Choy in the vertical aquaponics system was not significantly different among the PVC pipes. However, the majority of growth parameters value of Pak Choy in the gutter "A" was significantly higher compared to those rests of gutters in the horizontal system (Table 2). It seemed that the vertical system resulted in a better result than that horizontal system. However, according to Khandaker \& Kotzen (2018), the residues from the substrates can become blocked in a vertical system unlike 


\section{JURNAL BIDDJATI}

http://journal.uinsgd.ac.id/index.php/biodjati

the free flow of water in the horizontal system due to the irrigation plays an important role in vertical aquaponics.

\section{Environmental Factor Observation}

Based on the result of environmental factor observation found that the daily water temperature and $\mathrm{pH}$ of both aquaponics system are ranged between $22-26^{\circ} \mathrm{C}$ and 7.2-7.4 respectively. According to Somerville et al. (2014) and LeBannister (2016), it has met the temperature and the $\mathrm{pH}$ requirement for aquaponics. Moreover, a study conducted by Zou et al. (2016) found that aquaponics system could tolerate $\mathrm{pH}$ 6.0-9.0. We found that the TDS level in the vertical and horizontal aquaponics system was 666 and 682 ppm respectively. A study by Ma et al. (2017) found that the growth and $\mathrm{N}$ content of Pak Choy was significantly affected by $\mathrm{pH}$ value. The optimal $\mathrm{pH}$ for the shoot and root growth was 6.2 and 8.0 respectively. TDS represented the dissolved nutrient salts in the fish tanks due to waste from the fish and its feed. The TDS level of both aquaponics systems in this study was fluctuated and seemed to be increased up to week- 2 of the observation period that is potentially toxic to the fish. Dunwoody (2013) recommended that a TDS level of 200-400 ppm is sufficient for the aquaponics system. Therefore, in the week- 2 the groundwater has been added to the fish tanks. Although, the nutrient concentrations of the plant supplied by the fish in the aquaponics system are significantly lower for most nutrients compared to hydroponic systems. Nevertheless, this sufficient for green leafy vegetables that rarely need additional nutritional supplementation (Bittsanszky et al. 2016).

It seemed that the nutrient supplied by Nile Tilapia (Oreochromis niloticus) resulted in the higher fresh weight of Pak Choy as the studied by Estim et al. (2019). Mangmang et al. (2018) suggested that the importance of the inoculation of plant growth-promoting rhizobacteria (PGPR) to the vegetable seeds or seedling in the germination stage prior transferred to the aquaponics system. The addition of nitrogen-fixing bacteria consortium to the aquaponics system is also recommended by Ishak et al. (2018) to enhance Pak Choy growth performance. According to Palm et al. (2018), additional fertilizer is often used to supplement nutrients missing from the fish feed for the plants.

\section{Catfish Growth Parameters}

During the observation, there was no mortality of catfish in both aquaponics systems. Catfish length and FCR was a little bit higher $(0.9 \mathrm{~cm}$ and 0.03 respectively) in the vertical compared with those in the horizontal system; however, it was $2.6 \mathrm{~g}$ lower in body weight (Table 3 ). This value of FCR was better than the result of Arifin et al. (2017). The lower FCR value caused the lower feed cost (Sopha et al. 2015). A study by Wijaya et al. (2019) found that the catfish growth rate was correlated with stocking density. According to Besson (2017) and Arifin et al. (2017), FCR is an important parameter to identify the economic value and environmental impacts and as technical performance indicators in the aquaculture business. According to Sukoco et al. (2016), the FCR and catfish biomass was affected by the addition of probiotics to the aquaponics system.

\section{Aquaponic System}

Based on this study showed that the vertical aquaponic system gave a better result in terms of the growth parameter of Pak Choy. The vertical system is slightly complicated than that horizontal aquaponic system. However, it is more eye-catching design as home yard farming. The vertical system is a new 
Jurnal Biodjati 4(2):175-183, November 2019

\section{JURNAL BIDDJATI}

http://journal.uinsgd.ac.id/index.php/biodjati

trend in aquaponics, mainly in urban areas, to maximize the production using the vertical space. It is also can be used for demonstration and exhibition purposes (Palm et al., 2018). Moreover, Khandaker \& Kotzen (2018) stated that the vertical aquaponic system reduced the spatial requirement for plants so that the production more sustainable.
The inoculation of plant growth-promoting rhizobacteria (PGPR) to the vegetable seeds or seedling prior transferred to the aquaponics system as well as the addition of biofertilizer and probiotic to the aquaponic tanks needs to be done in the future study to increase the nitrification process for growth enhancement.

Table 2. The growth of Pak Choy in vertical and horizontal aquaponics system for 5 weeks after planting

\begin{tabular}{ccccc}
\hline $\begin{array}{c}\text { Grow beds (PVC } \\
\text { pipes/gutters) }\end{array}$ & $\begin{array}{c}\text { Survival rate } \\
(\%)\end{array}$ & $\begin{array}{c}\text { Leaf } \\
\text { Number }\end{array}$ & $\begin{array}{c}\text { Fresh weight } \\
(\text { gram })\end{array}$ & $\begin{array}{c}\text { Total leaf area } \\
\left(\mathrm{cm}^{2}\right)\end{array}$ \\
\hline & 100 & $\begin{array}{c}\text { Vertical } \\
12.0 \pm 0.4 \mathrm{a}\end{array}$ & $25.1 \pm 1.9 \mathrm{a}$ & $245.5 \pm 12.2 \mathrm{a}$ \\
$\mathrm{A}$ & 100 & $13.1 \pm 0.7 \mathrm{a}$ & $30.2 \pm 2.1 \mathrm{a}$ & $315.6 \pm 69.6 \mathrm{a}$ \\
$\mathrm{B}$ & 100 & $11.1 \pm 0.8 \mathrm{a}$ & $28.5 \pm 4.5 \mathrm{a}$ & $399.0 \pm 22.2 \mathrm{a}$ \\
$\mathrm{C}$ & 100 & $11.8 \pm 0.7 \mathrm{a}$ & $31.5 \pm 5.7 \mathrm{a}$ & $317.0 \pm 50.5 \mathrm{a}$ \\
$\mathrm{D}$ & 100 & Horizontal & & \\
$\mathrm{A}$ & 100 & $8.8 \pm 0.3 \mathrm{a}$ & $22.7 \pm 1.3 \mathrm{a}$ & $274.6 \pm 36.0 \mathrm{a}$ \\
$\mathrm{B}$ & 88 & $7.7 \pm 1.1 \mathrm{~b}$ & $14.4 \pm 2.2 \mathrm{~b}$ & $224.5 \pm 5.1 \mathrm{ab}$ \\
$\mathrm{C}$ & 100 & $8.2 \pm 0.4 \mathrm{~b}$ & $13.8 \pm 0.8 \mathrm{~b}$ & $168.7 \pm 12.5 \mathrm{~b}$ \\
$\mathrm{D}$ & & & & \\
\hline
\end{tabular}

Table 3. The growth of catfish in vertical and horizontal aquaponics system for 7 weeks after planting

\begin{tabular}{ccccc}
\hline Aquaponics systems & $\begin{array}{c}\text { Survival rate } \\
(\%)^{*}\end{array}$ & $\begin{array}{c}\text { Length } \\
(\mathrm{cm})^{*}\end{array}$ & $\begin{array}{c}\text { Weight } \\
(\text { gram })^{*}\end{array}$ & $\begin{array}{c}\text { Feed Conversion Ratio } \\
(\text { FCR })^{* *}\end{array}$ \\
\hline Vertical & 100 & $23.2 \pm 1.1$ & $96.3 \pm 13.2$ & 0.35 \\
Horizontal & 100 & $22.3 \pm 1.1$ & $98.9 \pm 15.6$ & 0.32 \\
\hline
\end{tabular}
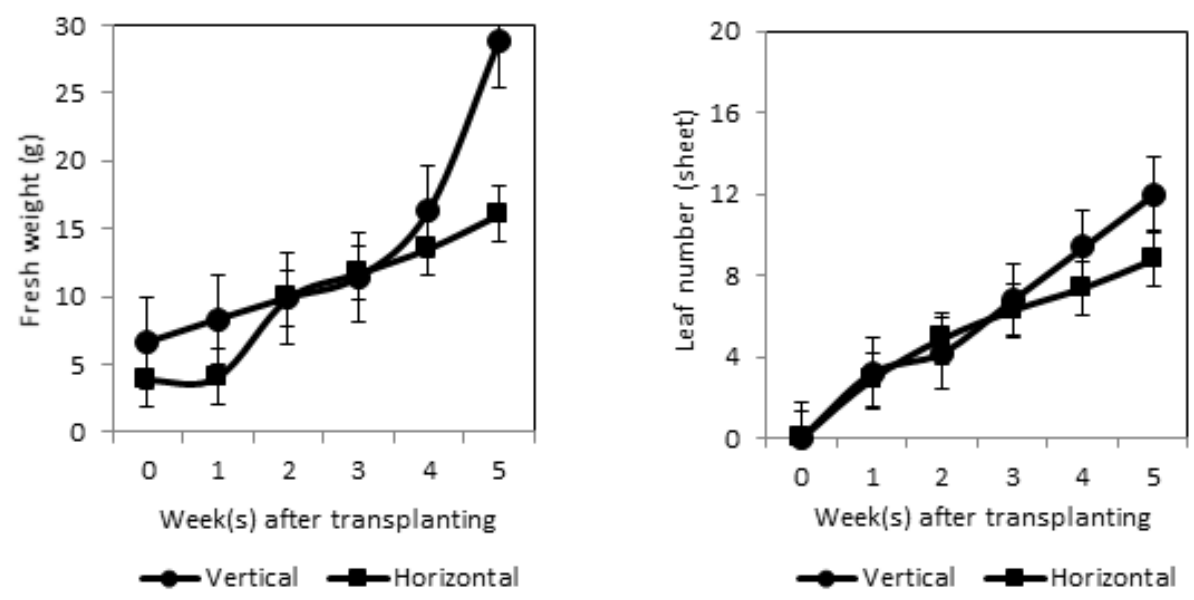

Figure 2. Growth pattern of A. Fresh weight and B. Leaf number of Pak Choy grown in household scale aquaponics systems 


\section{JURNAL BIDDJATI}

http://journal.uinsgd.ac.id/index.php/biodjati

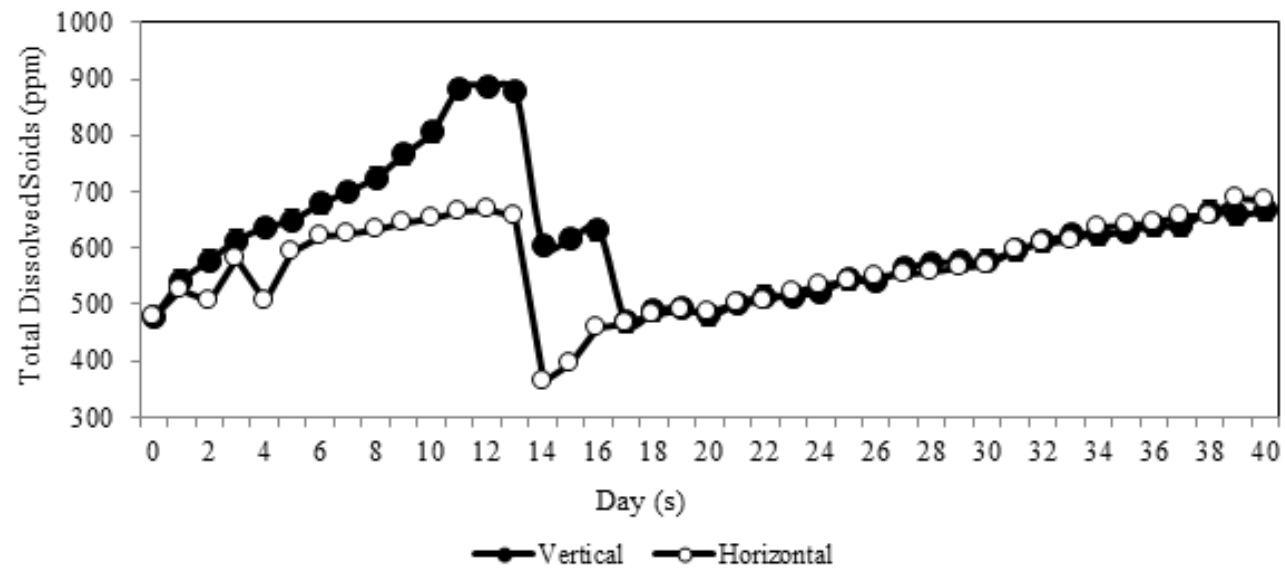

Figure 3. Total Dissolved Solids (TDS) level (ppm) in A. vertical and B. horizontal aquaponics system of Pak Choy- Catfish for 5 weeks
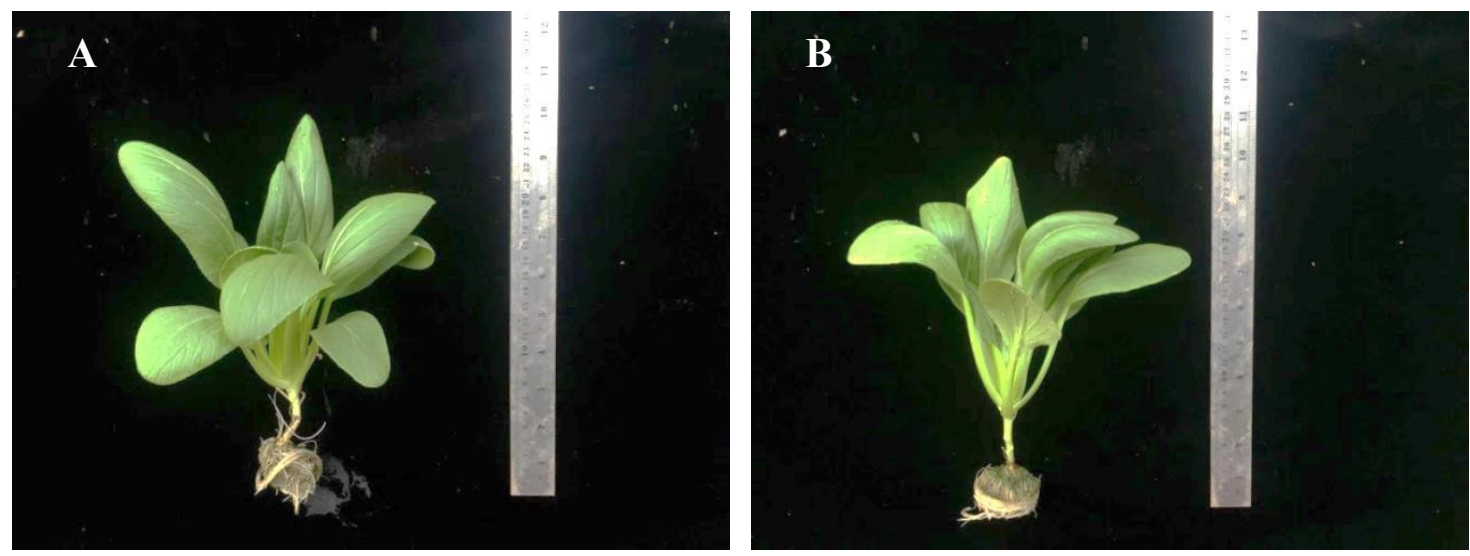

Figure 4. Performance of Pak Choy A. vertical and B. horizontal aquaponics system for 5 weeks

\section{ACKNOWLEDGMENTS}

The authors would like to thanks to Ms Naomi Geoviani Buyung, Mr Ajum and Yudi Slamet Hidayat for their technical assistance in the screenhouse during the experiment.

\section{REFERENCES}

Arifin, Z. \& Rumondang, R. (2017). Pengaruh Pemberian Suplemen Madu Pada Pakan Terhadap Pertumbuhan dan FCR Ikan Lele Dumbo (Clarias gariepinus). Fisherina: Jurnal Penelitian Budidaya Perairan, 1(1).
Besson, M. Aubin, J., Komen, H., Poelman, M., Quillet, E., Vandeputte, M., van Arendonk, J. A. M. \& de Boer, I. J. M. (2016). Environmental Impacts of Genetic Improvement of Growth Rate and Feed Conversion Ratio in Fish Farming Under Rearing Density and Nitrogen Output Limitations. Journal of Cleaner Production, 116, 100-109.

Bittsanszky, A., Uzinger, N., Gyulai, G., Mathis, A., Junge, R., Villarroel, M., Kotzen, B. \& Komives, T. (2016). Nutrient Supply of Plants in Aquaponic Systems. Ecocycles, 2(2), 17-20.

Bosma, R. H., Lacambra, L., Landstra, Y., 


\section{JURNAL BIDDJATI}

http://journal.uinsgd.ac.id/index.php/biodjati

Perini, C., Poulie, J., Schwaner, M. J. \& Yin, Y. (2017). The Financial Feasibility of Producing Fish and Vegetables through Aquaponics. Aquacultural Engineering, 78, 146-154.

Bradshaw, J. D., Rice, M. E. \& Hill, J. H. (2007). Digital Analysis of Leaf Surface Area: Effects of Shape, Resolution, and Size. Journal of the Kansas Entomological Society, 339-347.

Damanik, B. H., Hamdani, H., Riyantini, I. \& Herawati, H. (2018). Uji Efektivitas Bio Filter dengan Tanaman Air untuk Memperbaiki Kualitas Air pada Sistem Akuaponik Ikan Lele Sangkuriang (Clarias gariepinus). Jurnal Perikanan Kelautan, 9(1), 134-142.

Dunwoody, R. K. (2014). Aquaponics and Hydroponics: The Effects of Nutrient Source and Hydroponic Subsystem Design on Sweet Basil Production. Thesis. Missouri: Department of Biology and Agriculture University of Central Missouri

Effendi, H., Utomo, B. A., Darmawangsa, G. M. \& Karo-Karo, R. E. (2015). Fitoremediasi Limbah Budidaya Ikan Lele (Clarias Sp.) dengan Kangkung (Ipomoea aquatica) dan Pakcoy (Brassica rapa chinensis) dalam Sistem Resirkulasi. Jurnal Ecolab, 9(2), 80-92.

Estim, A., Saufie, S. \& Mustafa, S. (2019). Water Quality Remediation Using Aquaponics Sub-Systems as Biological and Mechanical Filters In Aquaculture. Journal of Water Process Engineering, 30.

Husnaeni, F. \& Setiawati, M. R. (2018). Pengaruh Pupuk Hayati dan Anorganik Terhadap Populasi Azotobacter, Kandungan $\mathrm{N}$ dan Hasil Pakcoy Pada Sistem Nutrient Film Technique. Jurnal Biodjati, 3(1), 90-98.

Ishak, M. F. B., Abdullah, T. A., Sajili, M. H.,
Mahmud, K. \& Mohamed, S. (2018). The Effect of Bacillus sp.(B43) on the Growth of Pak Choy and Red Tilapia in Aquaponics System. Journal of Agrobiotechnology, 9(1S), 154-165.

Khandaker, M. \& Kotzen, B. (2018). The Potential for Combining Living Wall and Vertical Farming Systems with Aquaponics with Special Emphasis on Substrates. Aquaculture Research, 49(4), 1454-1468.

Kuswoyo, A. \& Zein, M. (2018). Kajian Pemanfaatan Air Kolam Lele Dengan Substitusi Urin Kambing Sebagai Nutrisi Hidroponik Sayuran Organik. Agrisains, 4(1), 1-4.

LeBannister, M. (2016). Aquaponics: The key to a More Sustainable Future? Retrieved from https://www.maximumyield.com/ aquaponics-the-key-to-a-more-sustainable-future/2/944.

Li, C., Lee, C. T., Gao, Y., Hashim, H., Zhang, X., Wu, W. M. \& Zhang, Z. (2018). Prospect of Aquaponics for the Sustainable Development of Food Production in Urban. Chemical Engineering Transactions, 63, 475-480.

Love, D. C., Fry, J. P., Li, X., Hill, E. S., Genello, L., Semmens, K. \& Thompson, R. E. (2015). Commercial Aquaponics Production and Profitability: Findings from an International Survey. Aquaculture, 435, 67-74.

Ma, Q., Cao, X., Xie, Y., Gu, Y., Feng, Y., Mi, W., Yang, X. \& Wu, L. (2017). Effect of $\mathrm{pH}$ on the Uptake and Metabolism of Glycine in Pak Choi (Brassica chinensis L.). Environmental and Experimental Botany, 133, 139-150.

Mangmang, J. S., Deaker, R. \& Rogers, G. (2015). Maximizing Fish Effluent Utilization for Vegetable Seedling Production by Azospirillum brasilense. Proce- 


\section{JURNAL BIDDJATI}

http://journal.uinsgd.ac.id/index.php/biodjati

dia Environmental Sciences, 29, 179.

Palm, H. W., Knaus, U., Appelbaum, S., Goddek, S., Strauch, S. M., Vermeulen, T., Jijakli, M. H. \& Kotzen, B. (2018). Towards Commercial Aquaponics: A Review of Systems, Designs, Scales, and Nomenclature. Aquaculture International, 26(3), 813-842.

Pratama, W. D. \& Manan, A. (2017). Pengaruh Pemberian Probiotik Berbeda dalam Sistem Akuaponik terhadap Kualitas Air pada Budidaya Ikan Lele (Clarias sp.). Journal of Aquaculture Science, 1(1), 27-35.

Priadi, D. \& Nuro, F. (2017). Seedling Production of Pak Choy (Brassica rapa L.) Using Organic and Inorganic Nutrients. Biosaintifika: Journal of Biology \& Biology Education, 9(2), 217-224.

Rakocy, J. E., Masser, M. P. \& Losordo, T. M. (2006). Recirculating Aquaculture Tank Production Systems: Aquaponics-Integrating Fish nd Plant Culture. SRAC publication, 454(1), 1-16.

Salam, M. A., Asadujjaman, M. \& Rahman, M. S. (2013). Aquaponics for Improving High-Density Fish Pond Water Quality Through Raft and Rack Vegetable Production. World Journal of Fish and Marine Sciences, 5(3), 251-256.

Somerville, C., Cohen, M., Pantanella, E., Stankus, A. \& Lovatelli, A. (2014). Small-Scale Aquaponic Food Production: Integrated Fish and Plant Farming. FAO Fisheries and Aquaculture Technical Paper (589) : I.
Sopha, S., Santoso, L. \& Putri, B. (2015). Pengaruh Subtitusi Parsial Tepung Ikan dengan Tepung Tulang terhadap Pertumbuhan Ikan Lele Sangkuriang (Clarias gariepinus). e-Jurnal Rekayasa dan Teknologi Budidaya Perairan, 3(2), 403-410.

Sukoco, F. A., Rahardja, B. S. \& Manan, A. (2019). Pengaruh Pemberian Probiotik Berbeda dalam Sistem Akuaponik Terhadap FCR (Feed Convertion Ratio) dan Biomassa Ikan Lele (Clarias sp.). Journal of Aquaculture and Fish Health, 6(1), 24-31.

Surnar, S. R., Sharma, O. P. \& Saini, V. P. (2015). Aquaponics: Innovative Farming. International Journal of Fisheries and Aquatic Studies, 2(4), 261-263.

Tay, D. C. S. \& Toxopeus, H. (1994). Brassica rapa L. cv. group pak choi. In: Siemonsma JS \& Piluek K. Pudoc. PROSEA (Plant Resources South-East Asia) No. 8: Vegetables(2nd edition). Bogor: Prosea Foundation.

Wijaya, O. \& Boedi Setya Rahardja, P. (2019). Pengaruh Padat Tebar Ikan Lele terhadap Laju Pertumbuhan dan Survival Rate pada Sistem Akuaponik Jurnal Ilmiah Perikanan dan Kelautan, 6(1), 55-58.

Zou, Y., Hu, Z., Zhang, J., Xie, H., Guimbaud, C. \& Fang, Y. (2016). Effects of $\mathrm{pH}$ on Nitrogen Transformations in Media-Based Aquaponics. Bioresource technology, 210, 81-87. 